
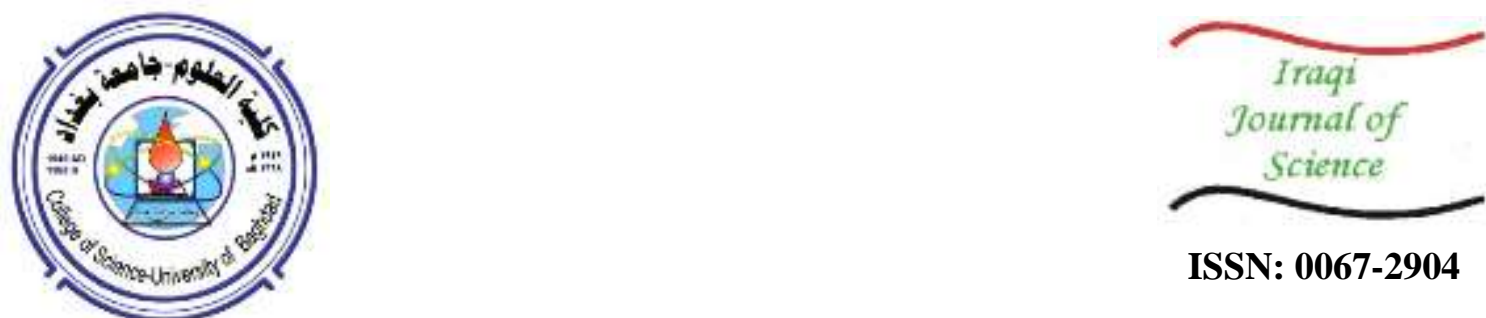

ISSN: 0067-2904

\title{
Synthesis and Characterization of Silver Nanoparticles Using Prodigiosin Pigment and Evaluation of Their Antibacterial and Anti-Inflammatory Activities
}

\author{
Oulan Alaa, Nadham Hassan
}

Department of Biotechnology, Collage of Since, University of Baghdad, Baghdad, Iraq

Received: $1 / 6 / 2020$

Accepted: 9/7/2020

\begin{abstract}
This study focused on the biological synthesis of silver nanoparticles (AgNPs), using prodigiosin pigment produced by Serratia marcescens. The effect of parameters such as $\mathrm{pH}$, temperature, time, with various concentrations of silver nitrate $\left(\mathrm{AgNO}_{3}\right)$ and prodigiosin on the synthesis of AgNPs were also studied. Optimized results of the biosynthesis process revealed an increase in the intensity of Surface Plasmon Resonance (SPR) bands of nanoparticles with shifting at the wavelength of $400 \mathrm{~nm}$. In addition, optimum synthesis of AgNPs was achieved at $\mathrm{pH} 12$, temperature $55^{\circ} \mathrm{C}$, and reaction time $24 \mathrm{~h}$, with concentrations of prodigiosin, as a reducing agent, of $12.5 \mu \mathrm{g} / \mathrm{ml}$ and silver ion concentration of $1 \mathrm{mM}$. Measurement of the size of silver nanoparticles by SEM diffraction revealed a value of $30 \mathrm{~nm}$. Finally, the minimum inhibitory concentration of AgNPs against pathogenic bacteria was $32 \mu \mathrm{g} / \mathrm{ml}$ for Staphylococcus aureus and Pseudomonas aeruginosa. The results of anti-inflammatory effects of Ag NPs obviously demonstrated that the infections of test animals treated with AgNPs were completely healed after 4 days of treatment, while the animals treated with fucidin (as control) did not exhibit any healing.
\end{abstract}

Keywords: prodigiosin, Silver nanoparticles, Characterization, Anti-inflammatory

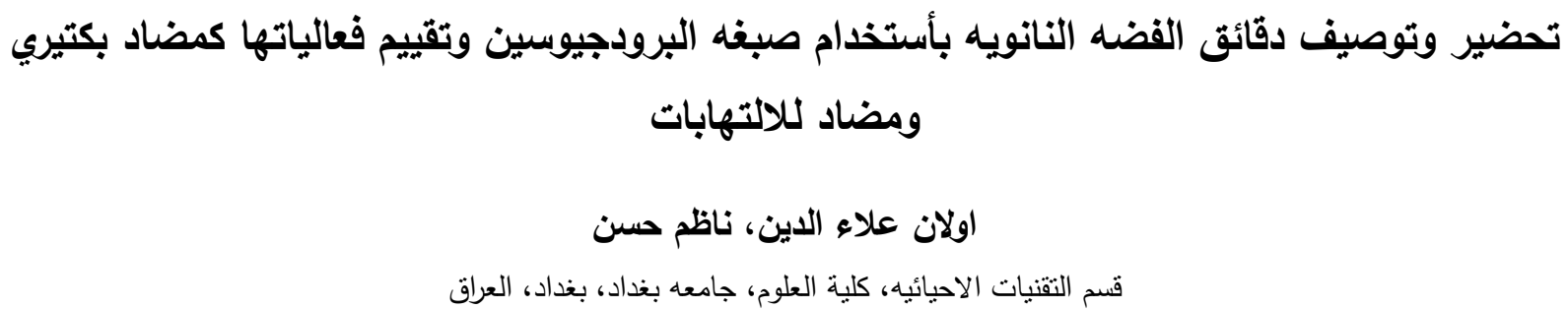

$$
\begin{aligned}
& \text { الخلاصه } \\
& \text { هدفت هذه الدراسه الى التصنيع الحيوي لدقائق الفضه النانويه بأستخدام صبغه البرودجيوسين المنتجة من }
\end{aligned}
$$

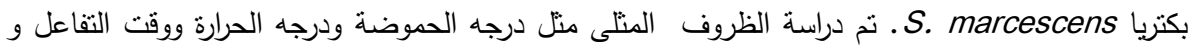

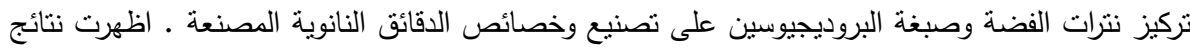

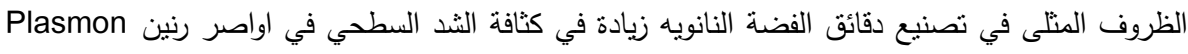

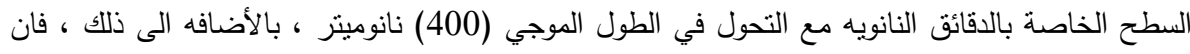

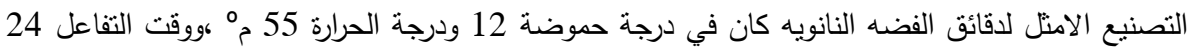

$$
\begin{aligned}
& \text { ساعه وعند التركيز } 12.5 \text { ميكروغرام / مل لصبغة البروديجيوسين ونترات الفضه بتركيز } 1 \text { ملي مول ـ ـوقد الاند } \\
& \text { اظهرت نتائج المجهر الالكتروني ان حجم دقائق الفضه النانويه المتكونة كان } 30 \text { نانوميتز ـ كما اظهرت }
\end{aligned}
$$




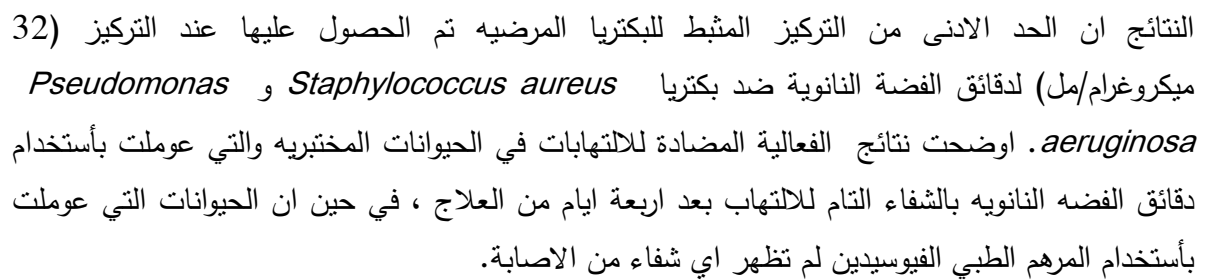

\section{Introduction}

Microorganisms such as bacteria and fungi are capable of biosynthesizing and regulating the metallic nanoparticles [1]. The biological processing of nanoparticles can have tremendous advantages over the traditional industrial one [2]. These nanoparticles are used for their antimicrobial activity, being used as surgical catheters for decreasing post-surgery infections in addition to their antifungal, anti-inflammatory, anti-angiogenic and permeability activities [3]. The production of nanomaterials has an increased reputation as participating in a wide diversity of applications in fields like electronics [4], photonics [5], catalysis [6], medicine [7], etc. These advantages and applications are due to the fact that the nano-state matter has different properties compared to the bulk state. Therefore, many researchers around the world are searching for new methods to produce materials at the nanoscale. Silver nanocrystals are generally synthesized from Ag+ solutions. Silver ions are obtained from a salt, such as silver nitrate $\left(\mathrm{AgNO}_{3}\right)$. At first, a reducing agent is sued to reduce the ions to atoms, which then nucleate into small groups that expand into nanoparticles. The shape and size of the nanoparticles depends on the presence of atoms, which in turn relies on percentage of silver salt available to reduce the concentration of the agent. Two components were required for the manufacture of nanoparticles in this method procedure; a silver salt as a precursor and a reduction and stabilization agent from Serratia marcescens, as well as prodigiosin (bacterial metabolite) pigments [8]. Prodigiosin, is a tri pyrrole nitrogen ring pigment [9]. Given its antimicrobial and immunomodulatory effects, this red pigment is a very favorable drug [10]. Prodigiosin is formed by Serratia marcescens following a bifurcated passage of biosynthesis, in which the discretely obtained mono-and bi-pyrrole precursors are linked in the stationary phase of bacterial growth to form the linear tri-pyrrole prodigiosin [11]. This study was designed to synthesize AgNPs using prodigiosin pigment as a reducing and stabilization agent. We also evaluated the biological activity of silver nanoparticles both in vitro as an antibacterial agent and in vivo as an anti - inflammatory agent in laboratory animals.

\section{Materials and methods}

\section{Bacterial isolate}

The bacterial isolate Serratia marcescens used in the present study for the production of prodigiosin was previously isolated from soil and obtained from biotechnology department, college of science, University of Baghdad. The identification of the bacterial isolate was confirmed using the VITEK 2 System.

\section{Pathogenic microorganisms used in the antibacterial activity test}

The pathogenic bacteria used in the current study were isolated from clinical cases and obtained from the College of Science, Department of Biotechnology. The identification of bacterial isolates was confirmed using the VITEK 2 System. The bacteria isolates used were Pseudomonas aeruginosa (isolated from burns) and Staphylococcus aureus (isolated from wounds).

Maintenance of pathogenic bacterial isolates was achieved by streaking on nutrient agar and incubation at $37^{\circ} \mathrm{C}$ for $24 \mathrm{hrs}$. The cultures were stored at $4{ }^{\circ} \mathrm{C}$ and then re-cultured every three weeks as an interval time.

\section{Production of prodigiosin from S. marcescens}

A defined liquid medium, described by [12], was used for the cultivation of $S$. marcescens isolate and prodigiosin production. The composition of this medium includes starch $10 \mathrm{~g} / \mathrm{l}$, peptone $5 \mathrm{~g} / \mathrm{l}$, $\mathrm{CaCl}_{2} .2 \mathrm{H}_{2} \mathrm{O} 8.82 \mathrm{~g} / \mathrm{l}, \mathrm{FeSO}_{4} .4 \mathrm{H}_{2} \mathrm{O} 0.33 \mathrm{~g} / \mathrm{l}, \mathrm{MgSO}_{4} .7 \mathrm{H}_{2} \mathrm{O} 0.61 \mathrm{~g} / \mathrm{l}$ and $\mathrm{MnSO}_{4} .4 \mathrm{H}_{2} \mathrm{O} 2 \mathrm{~g} / \mathrm{l}$. The $\mathrm{pH}$ of the medium was adjusted to 7 prior to autoclaving. After sterilization, the medium was left to cool, then inoculated with $1 \%$ of the selected bacterial isolate $\left(1 \times 10^{8} \mathrm{CFU} / \mathrm{ml}, \mathrm{OD}=0.5\right)$ and incubated in a shaker incubator at $30^{\circ} \mathrm{C}$ and $150 \mathrm{rpm}$ for $48 \mathrm{~h}$.

\section{Extraction of Prodigiosin Pigment}

The red pigment prodigiosin was extracted from the bacterial cell pellet as described by [13]. After incubation, the cultivated broth was centrifuged for 15 minutes at $10,000 \mathrm{rpm}$. The supernatant was 
removed, the cell pellet was suspended in 95 percent methanol, and the extract was treated for 3 minutes using an ultrasonic homogenizer until the solution became colorless. The mixture was vortexed and centrifuged for $15 \mathrm{~min}$ at $10,000 \mathrm{rpm}$. By using a Whatman filter paper of $45 \mu \mathrm{m}$, the extract then was filtered and transferred to a conical flask for methanol portion evaporation using a rotary evaporator. The dry weight was determined and the extract was stored in a glass tube covered with aluminum foil.

\section{Synthesis of silver nanoparticles using prodigiosin}

A concentration of $5 \mu \mathrm{g} / \mathrm{ml}$ of prodigiosin powder was mixed with deionized water (DI), then the aqueous silver nitrate $(\mathrm{AgNO} 3)$ solution $(1 \mathrm{mM})$ was added. The volume was ultimately completed to $20 \mathrm{ml}$ with DI. The reaction took place in $24 \mathrm{hrs}$. at $25^{\circ} \mathrm{C}$.

\section{Optimized conditions for nanoparticles synthesis Initial pH}

Silver nanoparticles were synthesized in different $\mathrm{pH}$ values $(5,7,9,11$ and 12$)$. The synthesis was performed using prodigiosin pigment with $\mathrm{AgNO}_{3}$ particles as mentioned above. The $\mathrm{pH}$ value was set with $0.1 \mathrm{~N} \mathrm{HCl}$ and $0.1 \mathrm{~N} \mathrm{NaOH}$.

\section{Temperature}

The effects of different temperature degrees on AgNPs synthesis were tested. The temperature values were $15,25,35,45$, and $55^{\circ} \mathrm{C}$. The production of silver nanoparticles was performed at an optimum $\mathrm{pH}$ as shown in a previous step.

\section{Effect of reaction time on synthesis of AgNPs}

The effect of reaction time for AgNPs synthesis was studied for 24 hrs. at regular intervals of 30 min. The shifting of color of the reaction mixture to dark brown indicated the formation of AgNPs, which was supported by UV - VIS spectrophotometry [14].

\section{Effect of silver nitrate concentration}

Various concentrations of $\mathrm{AgNO}_{3}$, ranging from 1 to $1000 \mathrm{mM}$, in test tubes containing $5 \mu \mathrm{g} / \mathrm{ml}$ prodigiosin were used to determine the effect of $\mathrm{AgNO}_{3}$ concentration on the synthesis of AgNPs. The reactions were incubated at optimal temperature and $\mathrm{pH}$ for an optimal time that was determined from the previous steps. Formation of AgNPs was confirmed by UV-visible spectrophotometry [15].

\section{Effect of prodigiosin concentration}

The effect of different concentrations of prodigiosin $(1,3,6,12.5,25,60,125,250$, and $500 \mu \mathrm{g} /$ $\mathrm{ml}$ ) on $\mathrm{AgNP}$ output was evaluated using $\mathrm{AgNO}_{3}$ at its optimum concentration and at the optimum $\mathrm{pH}$, temperature, and reaction time, as calculated in the previous experimental steps.

\section{Characterization of AgNPs}

UV - visible spectroscopy was used to confirm the formation of silver nanoparticles. Furthermore, sample patterns were determined by using XRD. FT - IR measurements were recorded to identify the major functional groups. Atomic force microscopy (AFM) for the determination of AgNPs surface morphology.

\section{Determination of minimum inhibitory concentration (MIC)}

MIC is the lowest concentration which inhibits the bacteria's visible growth. AgNPs MIC values were determined against two antibiotic resistant isolates, Staphylococcus aureus and Pseudomonas aeruginosa. These isolates were tested against many antibiotics and their resistance to many antibiotics was observed. A stock solution was prepared using different concentrations of AgNPs, ranging from 2-1024 $\mu \mathrm{g} / \mathrm{ml}$. AgNPs were dissolved in Mueller-Hinton broth and transferred into a microtiter plate. Overnight bacterial culture $(50 \mu \mathrm{l})$ was performed and the size of bacterial culture was adjusted to 0.5 . McFarland standard was added to each well with the exception of the negative control well which contained Mueller-Hinton broth. Wells that contained only bacterial cultures were considered as positive control. The microtiter plate was incubated overnight at $37^{\circ} \mathrm{C}$. After that, $10 \mu \mathrm{l}$ of Alamar blue added to each well and the culture was incubated again for $24 \mathrm{~h}$. The wells which showed no color change were considered as having the MIC that inhibits bacterial growth [16].

\section{Anti-inflammatory activity of AgNPs}

\section{Preparation of AgNPs cream}

The cream was prepared according to Atwan and Hayder [17] using the following ingredients: 25g of vaseline to collect components and protect the mixture from drying, $25 \mathrm{mg}$ of methyl paraben $(0.1 \%)$ as preservative, $1.25 \mathrm{ml}$ of glycerol (5\%) as a moisturizer and to prevent the skin from becoming dry, 
rough, scaly, itchy, and irritated. All the above components were mixed with the synthesized AgNPs at the concentration of MIC determined from the previous step. These ingredients were mixed and kept in the refrigerator until use.

\section{Anti-inflammatory activity test in vivo}

Laboratory animals (Rabbits) were used for the in vivo anti-inflammatory test. The animals were divided into two groups: control (A) and test (B) groups. For infecting the animals, both groups were subcutaneously injected with $1 \mathrm{ml}$ of the overnight activated clinical pathogen $S$. aureus and $P$. aeruginosa, with $\mathrm{OD}=0.5$. The animals were left for $48 \mathrm{hrs}$. for the appearance of pus, cracking, and finally inflammation of the skin. Thereafter, the inflammation test carried out by the daily wiping of the tested animals with the synthesized AgNPs cream until the healing of inflammation. Control animals were treated using Fucidin ointment (LEO pharma, Ireland) instead of the synthesized AgNPs cream.

\section{Results and Discussion \\ Identification of the prodigiosin producing isolate}

In this analysis carried out by the presence of intracellular shiny red pigmentation, the morphological characteristics of Serratia isolates appeared with colonies (Figure-1). Many marked signs appeared, such as the rod shape of cells under microscopic inspection and Gram negative staining. The ability of the bacterial isolate for prodigiosin production was confirmed by using VITEK2 compact system based on biochemical tests. The isolate exhibited 95\% similarity with the genus Serratia marcescens.
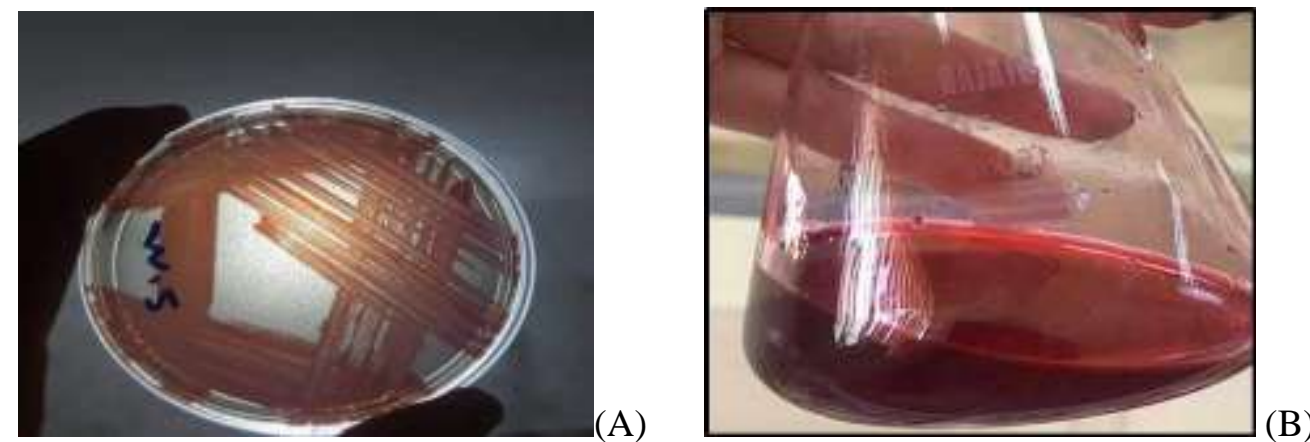

Figure 1- Growth of Serratia marcescens colonies on nutrient agar (A), production of prodigiosin pigment (B).

\section{Production and quantification of prodigiosin}

In this test, the optimized physical factors which are used to increase the output of prodigiosin were modified according to [18]. These included temperature (30 rpm) $\mathrm{pH}(7)$ and shaking rate in the shaker incubator $(150 \mathrm{rpm})$. The incubation was performed in dark since $S$. Marcescens typically develops in a dark environment and produces more intracellular prodigiosin to avoid phototoxicity. The maximum prodigiosin concentration that was produced from the isolate was $0.51 \mathrm{~g} / \mathrm{L}$, which occurred at $48 \mathrm{hrs}$. of incubation, when the cells reached their early stationary phase.

Cang et al. [19] notified that the maximum prodigiosin manufacturing was observed at $48 \mathrm{~h}$ and that it was completed by $72 \mathrm{hrs}$. Also, another study noticed that growth and manufacturing of prodigiosin starts after $48 \mathrm{hrs}$. of incubation and thereafter the production starts to decrease [20]

\section{UV-Visible analysis of AgNPs}

The synthesis of AgNPs was monitored by color change and UV-Vis spectroscopy. The formation of AgNPs was confirmed by the change in the solution color from colorless to brownish yellow (Figure-2). El-Batal et al. study [21] found that the AgNps synthesized by S. Marcescens collect WSE found to have maximum suction at $412 \mathrm{~nm}$, their thickness allocation was set by dynamic light scattering (DLS) and a medium particle size of $11.5 \mathrm{~nm}$. The peak enlargement is the best signal used to monitor nanoparticles size. As particle size increases, the plasmon resonance peak shifts to longer wavelengths. As the particle size increases, the suction peak converts to the red wavelength, indicating the output of larger nanoparticles [22, 23]. The absorption spectrum of spherical silver nanoparticles was reported to exhibit a maximum of $420 \mathrm{~nm}$ to $450 \mathrm{~nm}$, with a blue or red change when the particle size is decreased or increased, respectively [24, 25]. The silver nanoparticles generated by $S$ are for 
this purpose. WSE marcescens isolate is presenting a blue shifted plasmon peak is the most potent strain to silver nanoparticles produced. It is well known that a plasmon surface band of spherical silver nanoparticles exists about the $420 \mathrm{~nm}$ region [26, 27].

In order to achieve the optimum conditions for AgNP synthesis, different parameters were studied in this procedure, such as $\mathrm{pH}$, temperature, reaction time, and concentrations of silver nitrate and prodigiosin. In each step of the synthesis of ideal nanoparticles, samples are examined by using the UV-Vis spectroscopy in order to determine the optimum conditions in the synthesis and production of silver nanoparticles.

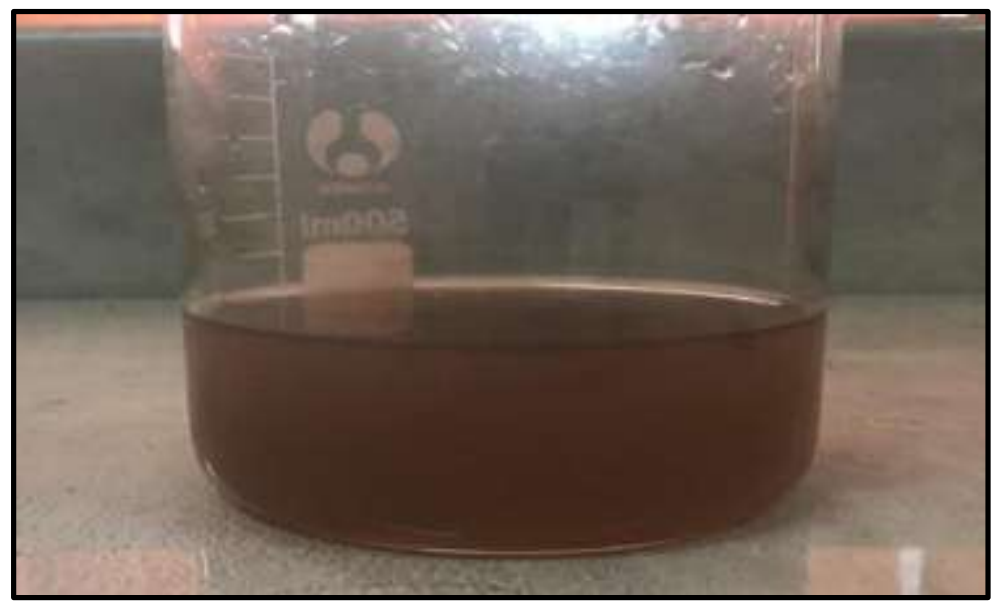

Figure 2-The formation of AgNPs as indicated by the change in the solution color from colorless to brownish yellow.

\section{Optimum conditions for AgNPs Synthesis}

\section{The Effect of pH on AgNPs Synthesis}

PH plays an important role in the creation of a mixture of nanoparticles by modifying their charges. Green synthesis of silver nanoparticles could achieve their stabilization when the natural material of concentrated prodigiosin $(5 \mu \mathrm{g} / \mathrm{ml})$ was used as a reduction and stabilization agent. The observed results indicated that the optimum $\mathrm{pH}$ for AgNP synthesis at a wavelength of $430 \mathrm{~nm}$ was 12, as shown in Table-1. The relation between the average size of silver nanoparticles and the $\mathrm{pH}$ values of the solution was examined. The surface plasmon peak was shown to move to the left as the $\mathrm{pH}$ value increases, indicating a reduction in the size of the prepared nanoparticles (Figure-3). The observed findings agree with those established earlier [28]. El-Batal et al., [29] reported the synthesis of AgNPs using prodigiosin pigment as a reduction agent. They found that the absorption spectrum of AgNPs with SPR band was blue-shifted due to a pH rise from 9 to 12 and showed a maximal absorption at $\mathrm{pH} 12$.

Table 1- Effects of different $\mathrm{pH}$ values on AgNPs synthesis

\begin{tabular}{|c|c|c|}
\hline NO. & pH & UV-Vis peak nm \\
\hline 1 & 5 & 220 \\
\hline 2 & 7 & 280 \\
\hline 3 & 9 & 310 \\
\hline 4 & 11 & 380 \\
\hline 5 & 12 & 430 \\
\hline
\end{tabular}




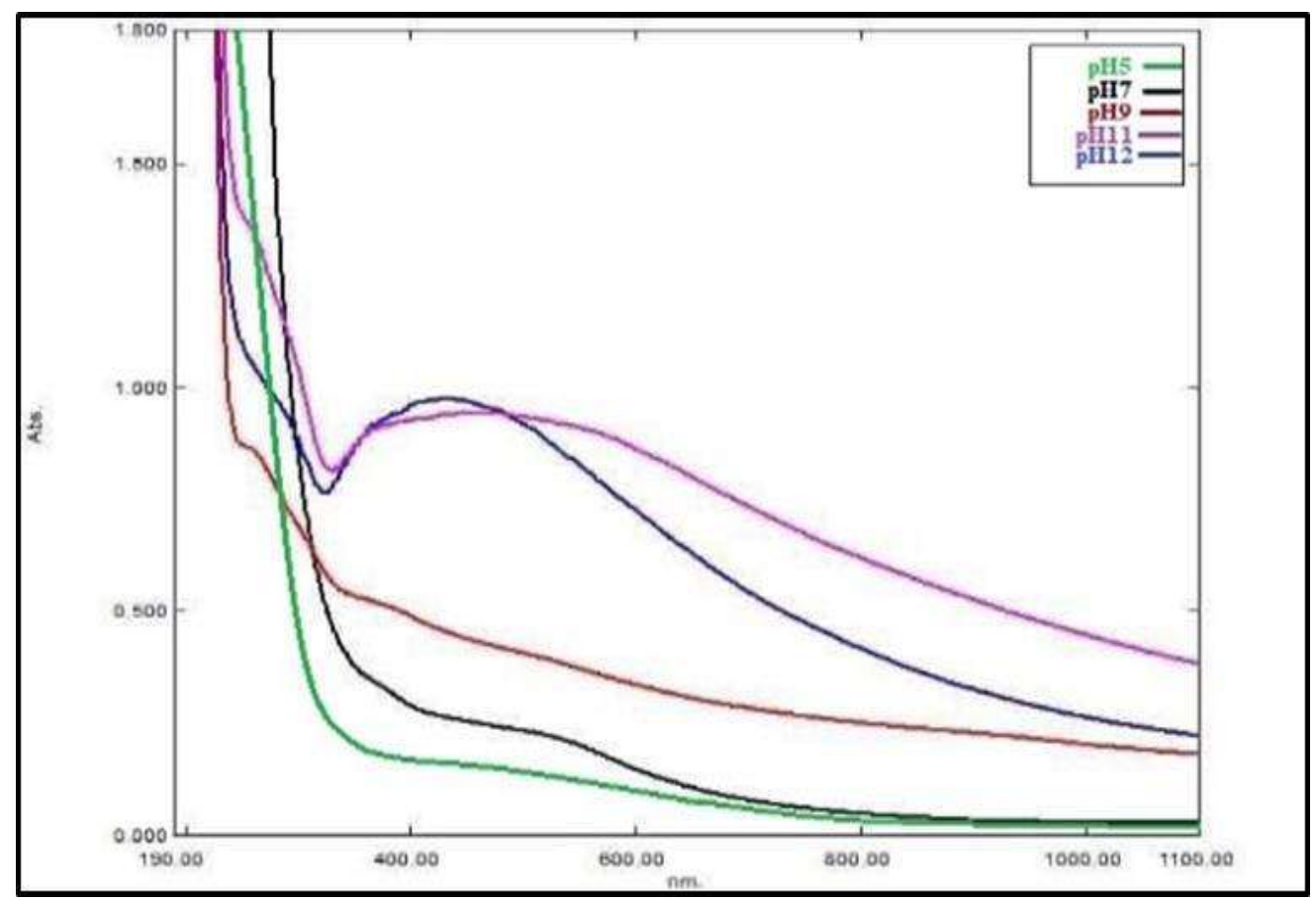

Figure 3-UV-Vis spectroscopy showing the effects of pH on AgNPs formation.

\section{Effects of temperature}

Temperature elevation normally increases reaction rate and the efficiency of synthesis. Most experiments are carried out at room temperature because it is the easiest and most efficient method of synthesizing nanoparticles. When the temperature increases, the reaction time reduces and the conversion to nanoparticles is completed by 95 percent within a limited period. The mixture was exposed to different temperatures $\left(15,25,35,45\right.$, and $\left.55^{\circ} \mathrm{C}\right)$, as shown in Table-2, with an ideal interaction condition that was obtained from the results of previous steps. The result showed that $55^{\circ} \mathrm{C}$ was the optimum temperature for synthesis of AgNPs at the wavelength of $413 \mathrm{~nm}$ (Figure-4). The results are in agreement with that mention by $\mathrm{Li}$ et al. [30]. Also, approximately similar results were obtained in the study conducted by El-Batal et al. [31]. Due to the increase in reaction temperature from $20^{\circ} \mathrm{C}$ to $70^{\circ} \mathrm{C}$, they showed a red shift of the SPR band. However, the increase from $80^{\circ} \mathrm{C}$ to $100^{\circ} \mathrm{C}$ resulted in a decrease in the wavelength of the absorbance peaks with a small blue shift for the synthesized AgNPs.

Table 2- Effects of different temperatures on AgNPs synthesis

\begin{tabular}{|c|c|c|}
\hline NO. & Temperature & UV-Vis peak $(\mathrm{nm})$ \\
\hline 1 & $15^{\circ} \mathrm{C}$ & 450 \\
\hline 2 & $25^{\circ} \mathrm{C}$ & 493 \\
\hline 3 & $35^{\circ} \mathrm{C}$ & 488 \\
\hline 4 & $45^{\circ} \mathrm{C}$ & 420 \\
\hline 5 & $55^{\circ} \mathrm{C}$ & 413 \\
\hline
\end{tabular}




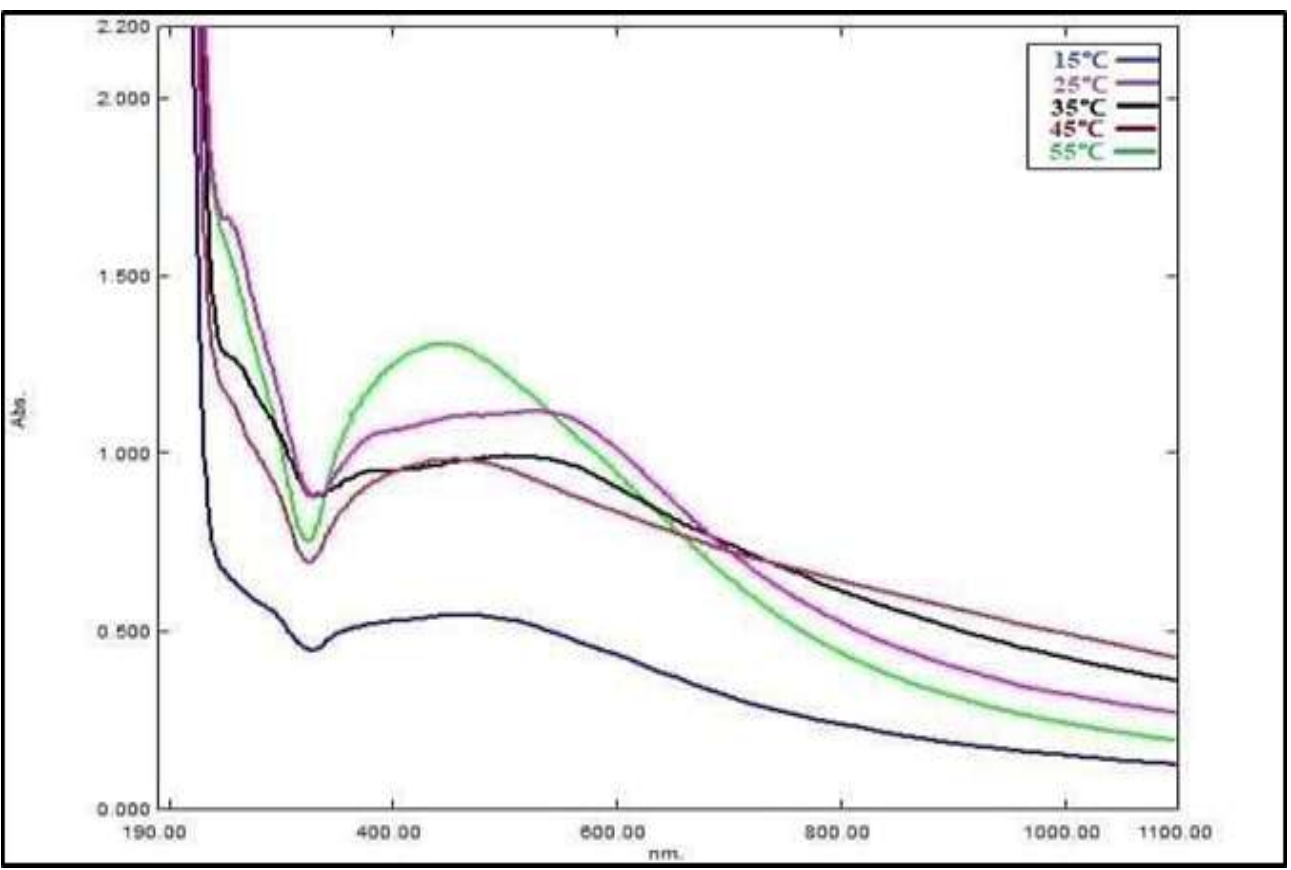

Figure 4-UV-Vis spectroscopy showing the effects of different temperature values on the synthesis of AgNPs at $\mathrm{pH}=12$.

\section{Effects of reaction time on the synthesis of AgNPs}

Time is one of the important parameters which directly affect nanoparticles biosynthesis. The reduction reaction for the production of nanoparticles started when reducing agents were instantly applied to the silver nitrate solution, which is demonstrated by the color transition from white to brown. Nevertheless, it is shown that particle size decreases with increasing time, and at a given time, it stabilizes. The mixture was subjected to various time intervals for AgNPs synthesis $(0.5,1,2,3$ and $24 \mathrm{hrs}$.), as seen in Table-3, taking into account the effects of optimal conditions in the previous steps. Maximum synthesis of AgNPs was observed at 24 hours at a wavelength of $410 \mathrm{~nm}$ (Figure-5). Increasing the reaction time provides the opportunity to complete the formation of nanoscale silver [32].

Aslan et al. [33] and E-Batal et al. [34] performed UV -Vis spectral analysis to validate synthesis of silver nanoparticles, after $24 \mathrm{hrs}$., using prodigiosin as a reducing agent. The results showed that the standard absorption spectrum of AgNPs is between $350 \mathrm{~nm}$ and $450 \mathrm{~nm}$.

Table 3-Effects of different time values on AgNPs synthesis.

\begin{tabular}{|c|c|c|}
\hline NO. & Time (hrs.) & UV-Vis peak (nm) \\
\hline 1 & 0.5 & 230 \\
\hline 2 & 1 & 210 \\
\hline 3 & 2 & 280 \\
\hline 4 & 3 & 279 \\
\hline 5 & 24 & 410 \\
\hline
\end{tabular}




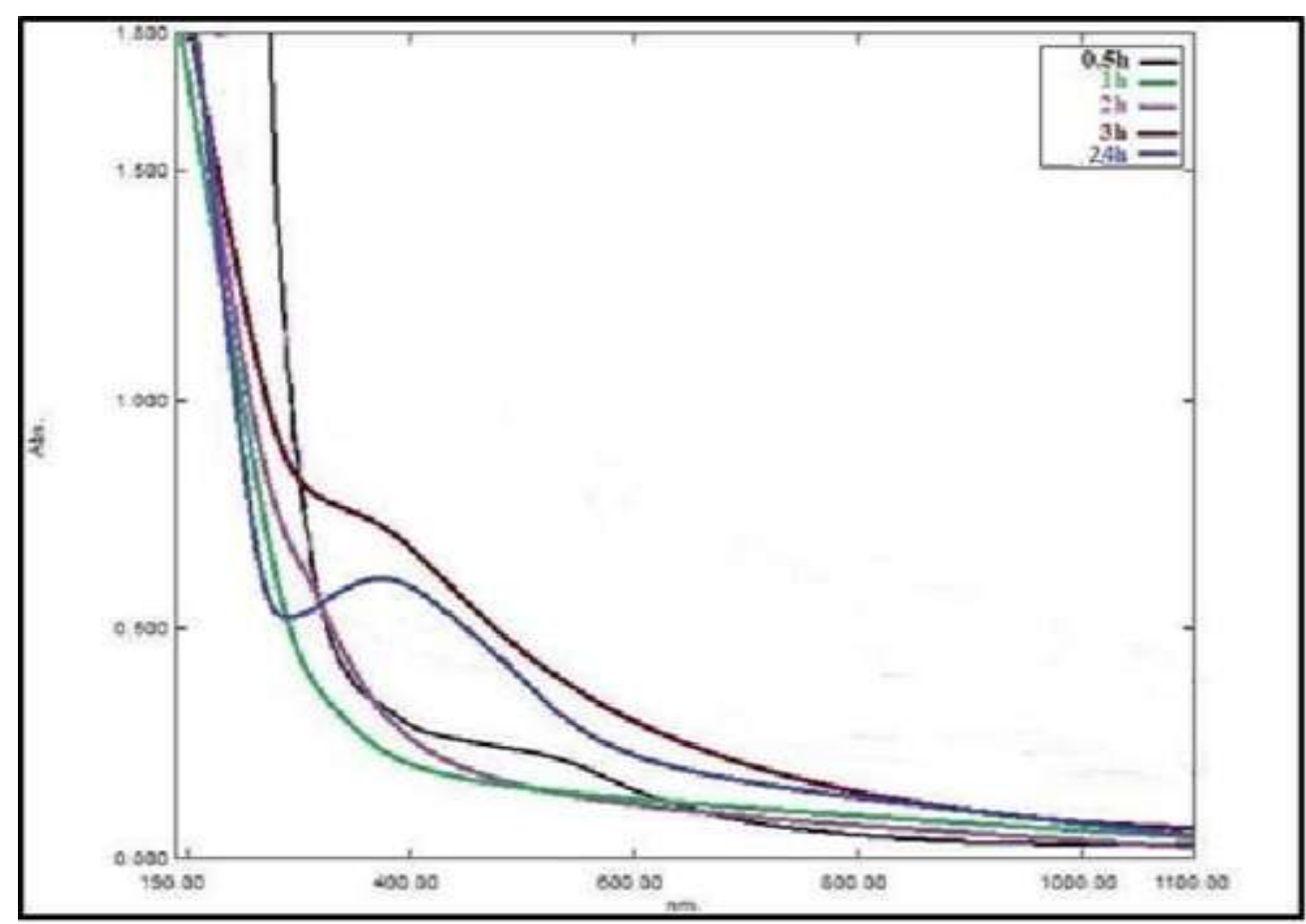

Figure 5- UV-Vis spectroscopy of AgNPs showing the effects of reaction time on the synthesis of AgNPs at $\mathrm{pH}=12$ and temperature $=55^{\circ} \mathrm{C}$.

\section{Effects of $\mathrm{AgNO}_{3}$ concentration on the synthesis of AgNPs}

The concentration of the silver nitrate solution used also affects the formation of AgNPs. At first, neutral silver atoms react with each other, forming stable nuclei and creating nanoparticles, until all metal ions are consumed. Thus, an introduction of protective agents must be sought to stop aggregation by their interactions with small particles [35]. Different concentrations of silver nitrate (1, $10,25,50,100,200,400,800$ and $1000 \mathrm{mM}$ ), as shown in Table-4, were added to solutions of prodigiosin $(5 \mu \mathrm{g} / \mathrm{ml})$ using the above described optimum conditions $\left(\mathrm{pH} 12\right.$, temperature $55^{\circ} \mathrm{C}$, and reaction time $24 \mathrm{hrs}$.). The results showed that the best concentration of silver ion was $1 \mathrm{mM}$ for the synthesis of nanoparticles at the wavelength of $415 \mathrm{~nm}$, as shown in Figure-6. The same results were observed by Vanaja et al., [36], who found that the concentration of $\mathrm{AgNO}_{3}$ of $1 \mathrm{mM}$ was typical for the maximum reducing reaction to form AgNPs. El-Batal et al. [37] also observed a red shift in the SPR due to the gradual increase in $\mathrm{AgNO}_{3}$ concentration (from 1 to $10 \mathrm{mM}$ ), using prodigiosin as a capping agent. TEM images show spherical nanoparticles at a concentration of 1mM AgNO3, with a mean diameter of $14.11 \mathrm{~nm}$.

Table 4-Effects of different concentrations of silver nitrate on AgNPs synthesis

\begin{tabular}{|c|c|c|}
\hline NO. & Concentration $(\mathrm{mM})$ & UV-Vis peak $(\mathrm{nm})$ \\
\hline 1 & 1 & 415 \\
\hline 2 & 10 & 497 \\
\hline 3 & 25 & 411 \\
\hline 4 & 50 & 385 \\
\hline 5 & 100 & 371 \\
\hline 6 & 200 & 374 \\
\hline 7 & 400 & 378 \\
\hline 8 & 800 & 369 \\
\hline 9 & 1000 & 220 \\
\hline
\end{tabular}




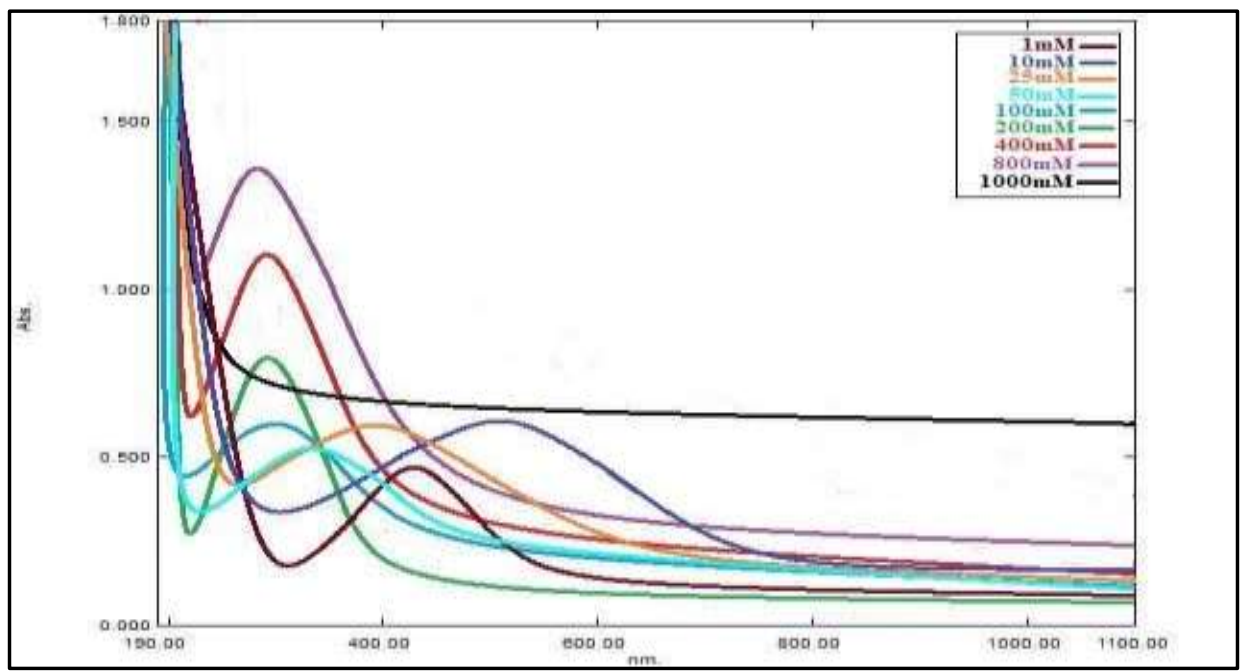

Figure 6-UV-Vis spectroscopy showing the effects of silver ion concentration on the synthesis of $\mathrm{AgNPs}$ at $\mathrm{pH} 12$, temperature $55^{\circ} \mathrm{C}$, and reaction time $24 \mathrm{hrs}$.

\section{Effects of prodigiosin concentration on synthesis of AgNPs}

One of the values of developing environmentally sustainable materials that are relevant to metallic nanoparticles synthesis is the application of prodigiosin as a caping agent. The concentration of prodigiosin applied to the mixture has an impact on the formation of silver nanoparticles, simultaneously acting as an agent for reduction and stabilization. The effect of partially purified prodigiosin concentration on the AgNPs synthesis was studied by adding different levels of prodigiosin $(3,6,12.5,25,50,100,200,400$ and $500 \mu \mathrm{g} / \mathrm{ml})$ based on the previously tested optimum conditions, as shown in Table-5. The results clearly show that the prodigiosin concentration of $12.5 \mu \mathrm{g} / \mathrm{ml}$ was ideal for AgNPs synthesis at $425 \mathrm{~nm}$ wavelength, as shown in Figure-7. The results The results of the current study are in accordance with the findings of El-Batal et al. [38].

Table 5-Effects of different concentrations of prodigiosin on AgNPs synthesis

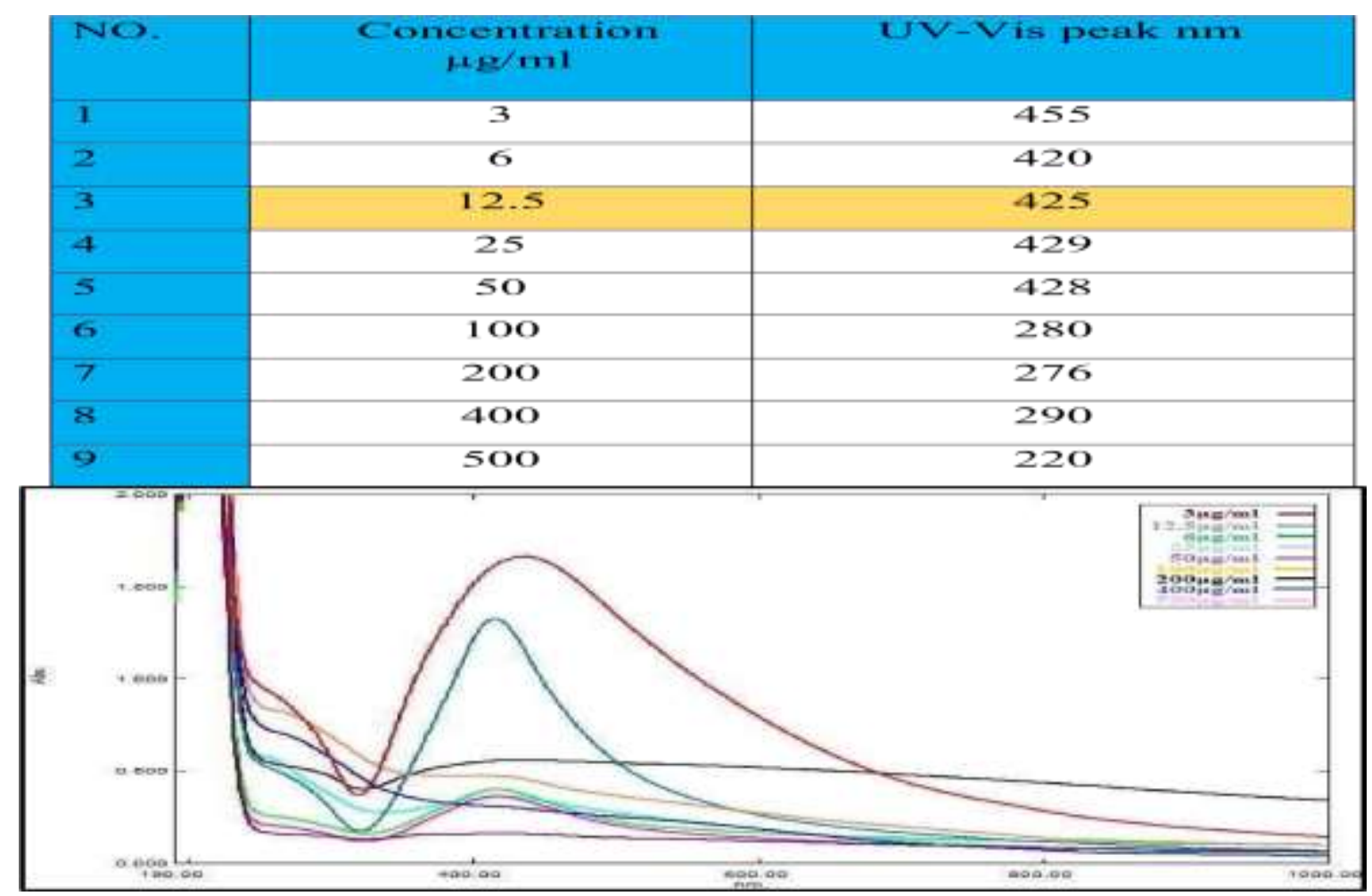

Figure 7-UV-Vis spectroscopy showing the effects of prodigiosin concentration on the synthesis of AgNPs at $\mathrm{pH} 12$, temperature $55^{\circ} \mathrm{C}$, reaction time $24 \mathrm{~h}$, and $1 \mathrm{mM}$ of $\mathrm{AgNO}_{3}$. 


\section{FT-IR analysis}

FT-IR measurements were conducted to identify the major functional groups of prodigiosin and examine their potential involvement in AgNPs synthesis and capping. The FTIR spectra of the red pigment revealed many degrees of similarity to the typical prodigiosin spectra [39]. FT-IR spectrum of prodigiosin shows different bands positioned at 3421, 2858, 1045, and $779 \mathrm{~cm}-1$ (Figure-8). The presence of $3421 \mathrm{~cm}^{-1}$ bands contributes to the $\mathrm{N}-\mathrm{H}$ stretch. The peaks of $2851 \mathrm{~cm}-1$ are typical of symmetrical stretching of aromatic methylene groups $(\mathrm{CH})$ [40]. The $\mathrm{C}-\mathrm{O}$ stretching was due to the $1045 \mathrm{~cm}-1$ peak. The value assigned to prodigiosin carbon-carbon double bond was observed at about $779 \mathrm{~cm}-1$ [41, 42]. FT-IR spectrum was tested for the AgNO3 synthesis (Figure-8). The band attached at $1380 \mathrm{~cm}-1$ was for the $(\mathrm{N}-\mathrm{O})$ stretching. FT-IR spectrum analyses for AgNPs aqueous solution and the emerged functional prodigiosin group bands after washing were detected. The peaks at $1674 \mathrm{~cm}-1$ was found only due to the combination of AgNPs with the feature groups of - NH prodigiosin [43]. This indicates that prodigiosin was formed by AgNPs as a capping agent for synthesis. However, the AgNPs band at $1380 \mathrm{~cm}^{-1}$ moved to a different location and appeared at $1364 \mathrm{~cm}-1$ band (Figure-8), which is another confirmation of AgNPs synthesis.

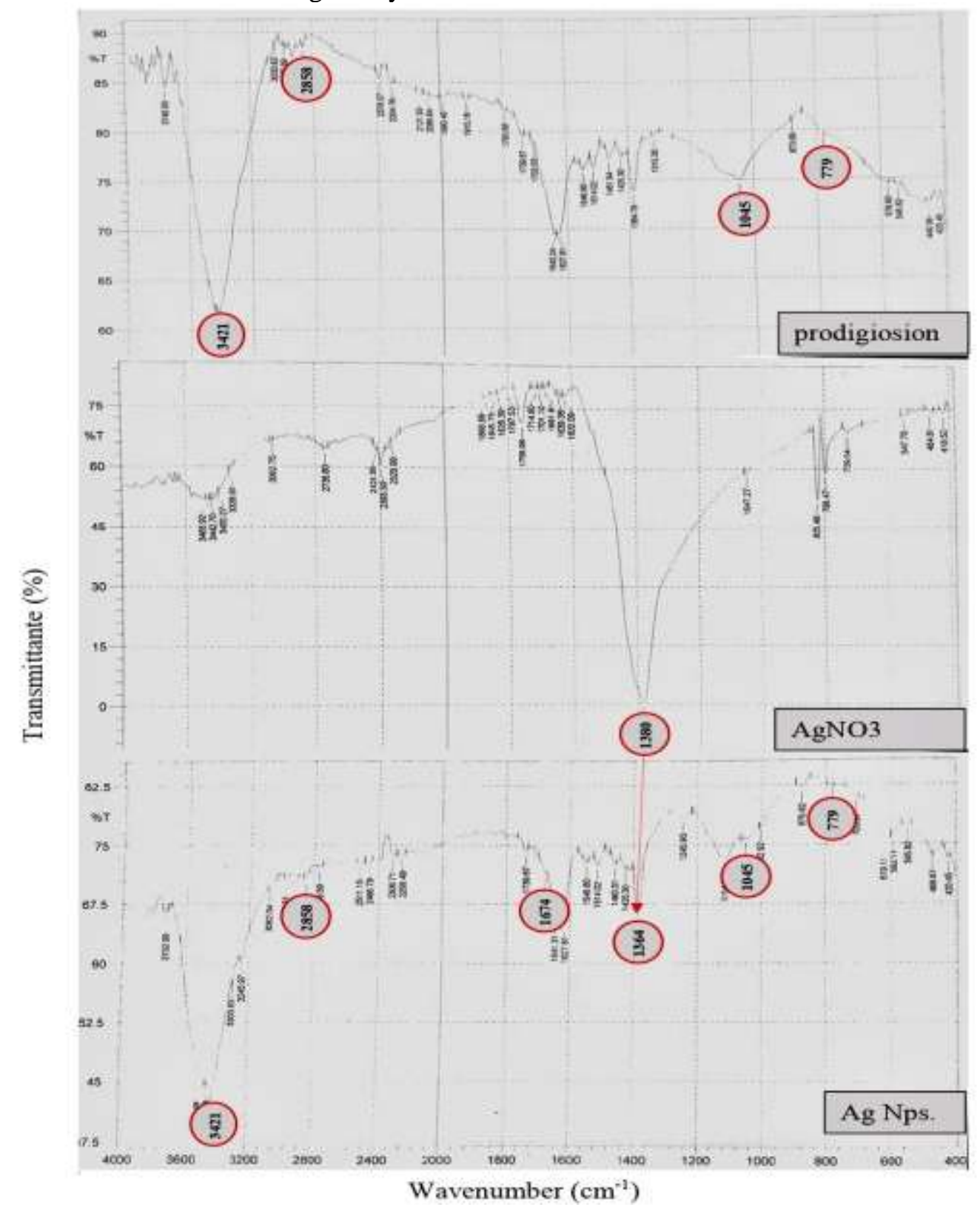

Figure 8-The Fourier transform infrared (FT-IR) spectroscopy measurement of prodigiosin, $\mathrm{AgNO}_{3}$, and AgNPs. 


\section{X-ray Diffraction analysis}

Figure-9 of the XRD patterns showed distinctive diffraction peaks of AgNPs at 2 ranges $=35,44$ ranges, 38,07 ranges, 44,39 ranges, and 64,42 ranges. These peaks were similar to the regular diffraction data for AgNPs (JCPDS file number 040783) and are assigned to ranges (111), (200), (227) and (309). Silver with $\mathrm{a}=4.0862 \AA$ lattice parameter approximately agreed with a comparison of the metallic silver metallic face - centered cubic (fcc) lattice [44].

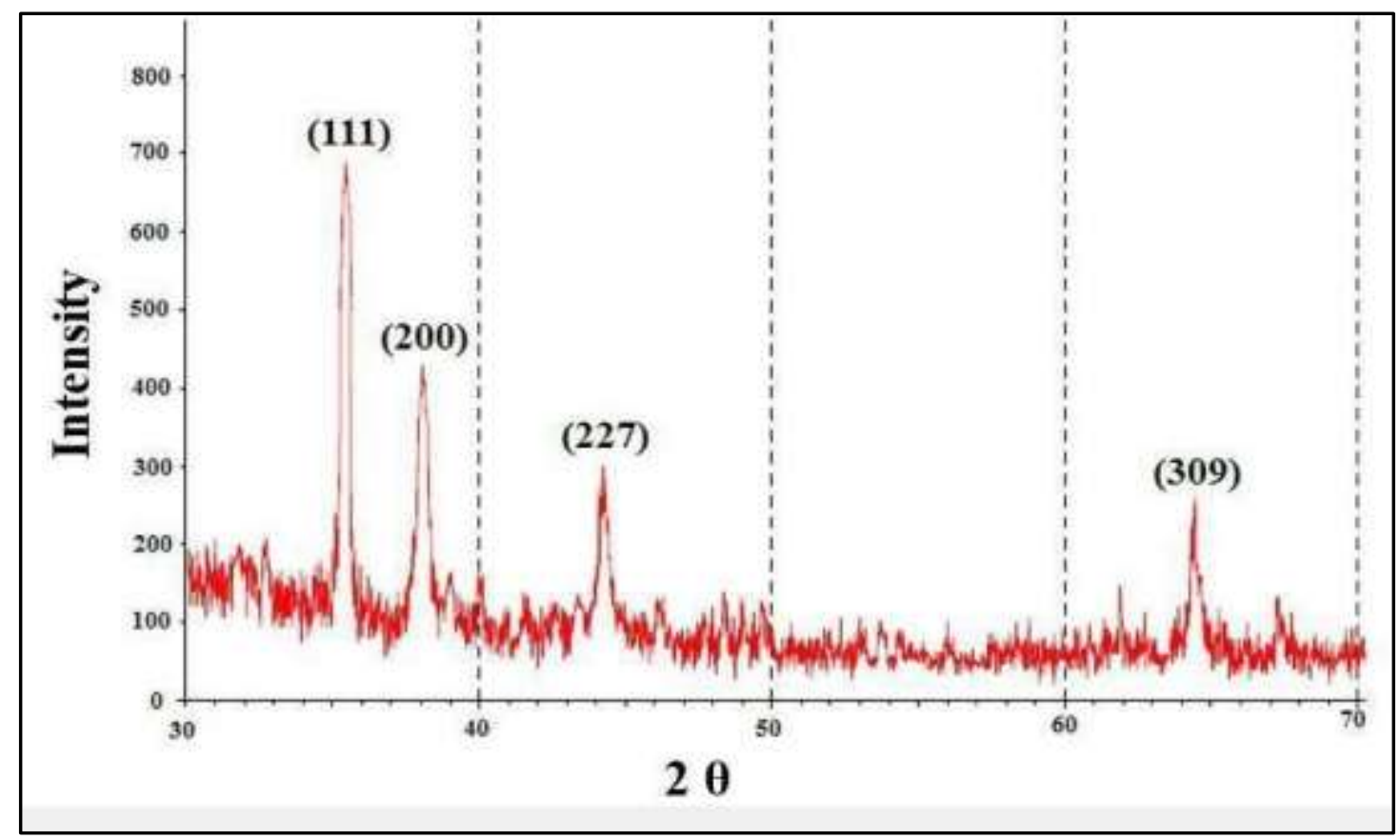

Figure 9-X-ray Diffraction (XRD) for AgNPs.

\section{Atomic Force Microscope (AFM)}

Atomic force microscope was used to determine topography and surface morphology. The AFM, at an atomic level, provides two-dimensional and three-dimensional representations of the nanoparticles surface [45], as displayed in Figure -10. The average diameter of particles measured was found to be on the nanoscale. The scale of silver nanoparticles was measured using AFM-SPM, and the results show that the AgNPs average size was $69 \mathrm{~nm}$, as illustrated in Figure-11.

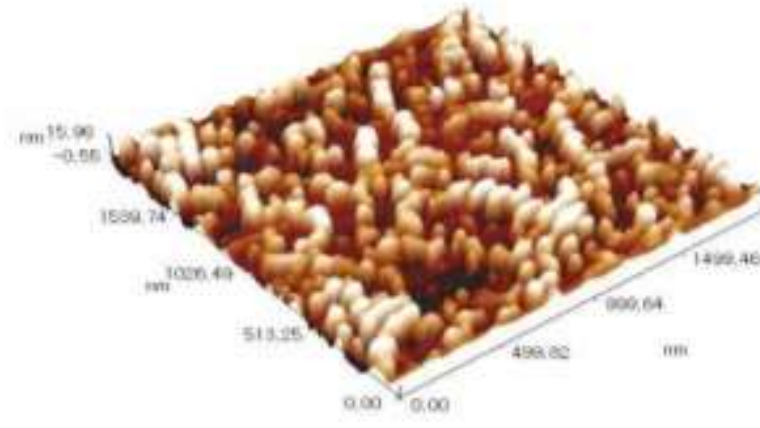

AFM 2D

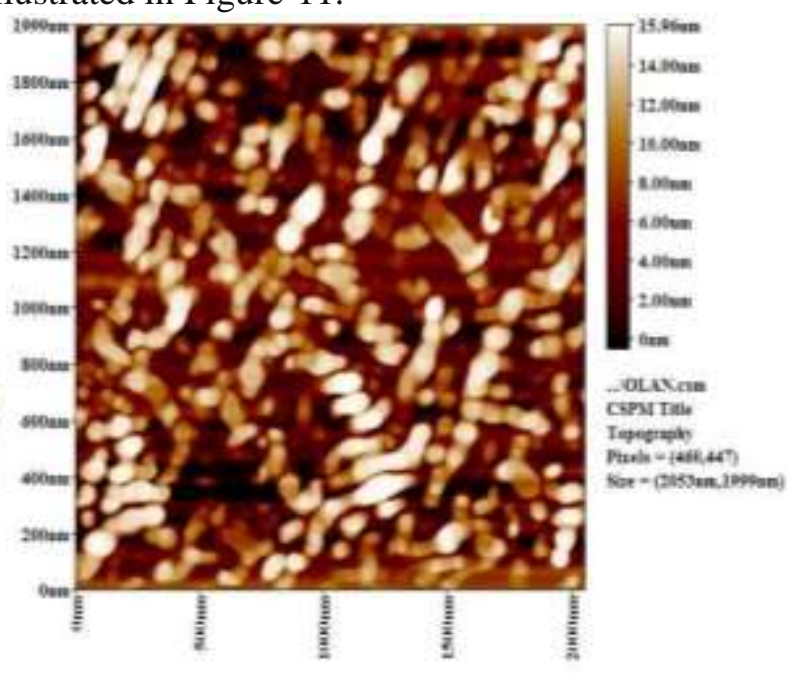

AFM 3D

Figure 10-Atomic force microscopy results of AgNPs as illustrate in 2D and 3D topology of silver nanoparticles. 


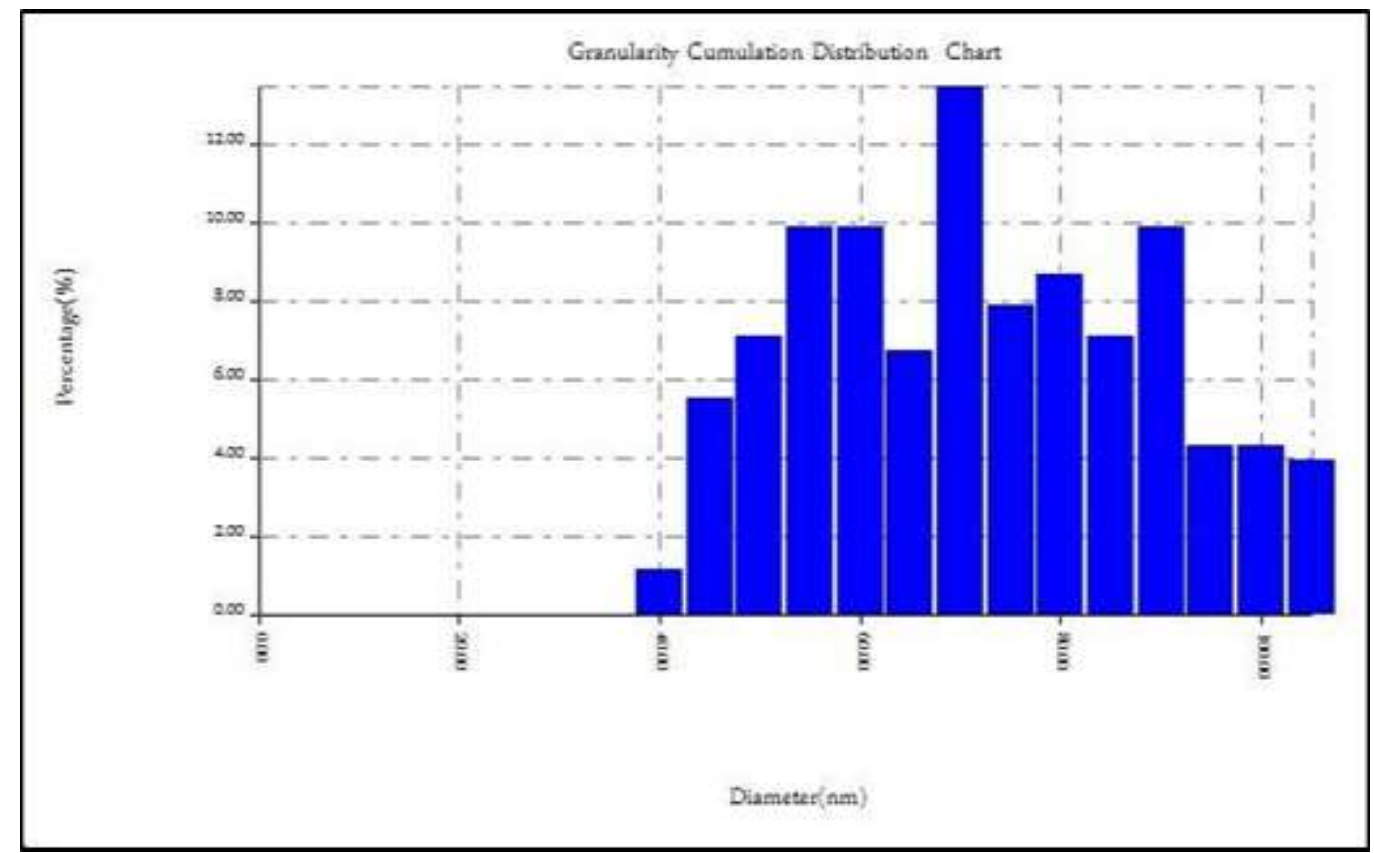

Figure 11- Average size of silver nanoparticles.

\section{Scanning electron microscope analysis of silver nanoparticles}

The results of the morphology and size distribution of the synthesized AgNPs by using prodigiosin are demonstrated through the SEM images in Figure-12. The surface of nanoparticles is smooth with good crystallinity and spherical shape [46]. The average particles size and distribution are determined randomly on the SEM. The most prevalent particles size range of the AgNPs is about 30 to $70 \mathrm{~nm}$.

Ullah et al. [47] showed that NPs studied by SEM were dispersed on the surfaces, preserved a good uniformity, and seemed to be less agglomerated. The cause of minimal aggregation of the nano-silver material might be because of its encapsulation with bio-molecules.

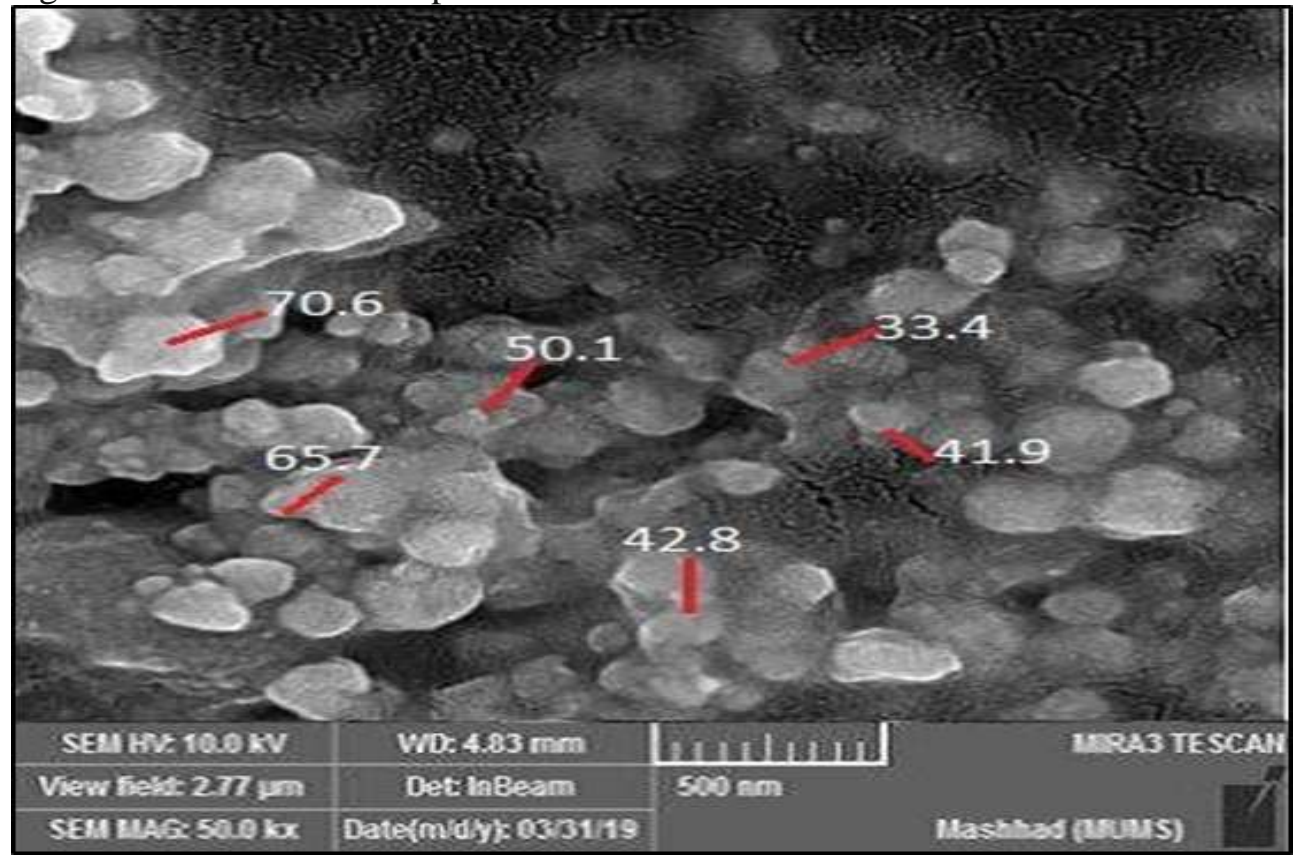

Figure 12- SEM image of silver nanoparticles

\section{Determination of minimal inhibitory concentration}

In the current study, different concentrations of AgNPs $(2-1024 \mu \mathrm{g} / \mathrm{ml})$ dissolved in MuellerHinton broth were transferred against pathogenic bacteria, P. aeruginosa and S. aureus, within micro titer plates. For this experiment, the violet pigment was used to confirm MIC values for the bacterial 
isolated, as illustrated by the change of pigment color from blue to pink. The pink color of the well refers to bacterial growth, while the MIC value is that of the well that is located directly before the first pink well. The results suggested that the MIC was $32 \mu \mathrm{g} / \mathrm{ml}$ for both isolates, as shown in Figure-13. Silver nanoparticles destroy bacteria by interfering with their outer membrane, causing structural changes that lead to degradation of the microbes and eventually death [48]. Silver nanoparticles adhere to microbial cells. Then, the most popular antimicrobial mode of action was recognized as cell membrane penetration and ROS and free radical generation [49]. To metabolize oxygen, all bacteria use an enzyme as a part of the "chemic lung." The silver ions disable the enzyme and stop oxygen acquisition [50]. Synthesized AgNPs have a stronger antibacterial effect on Pseudomonas spp, followed by $E$. coli. Silver ions are well known for their strong bacteriostatic and bactericidal effects $[51,52]$.

Table 5-Effects of different concentrations of prodigiosin on AgNPs synthesis

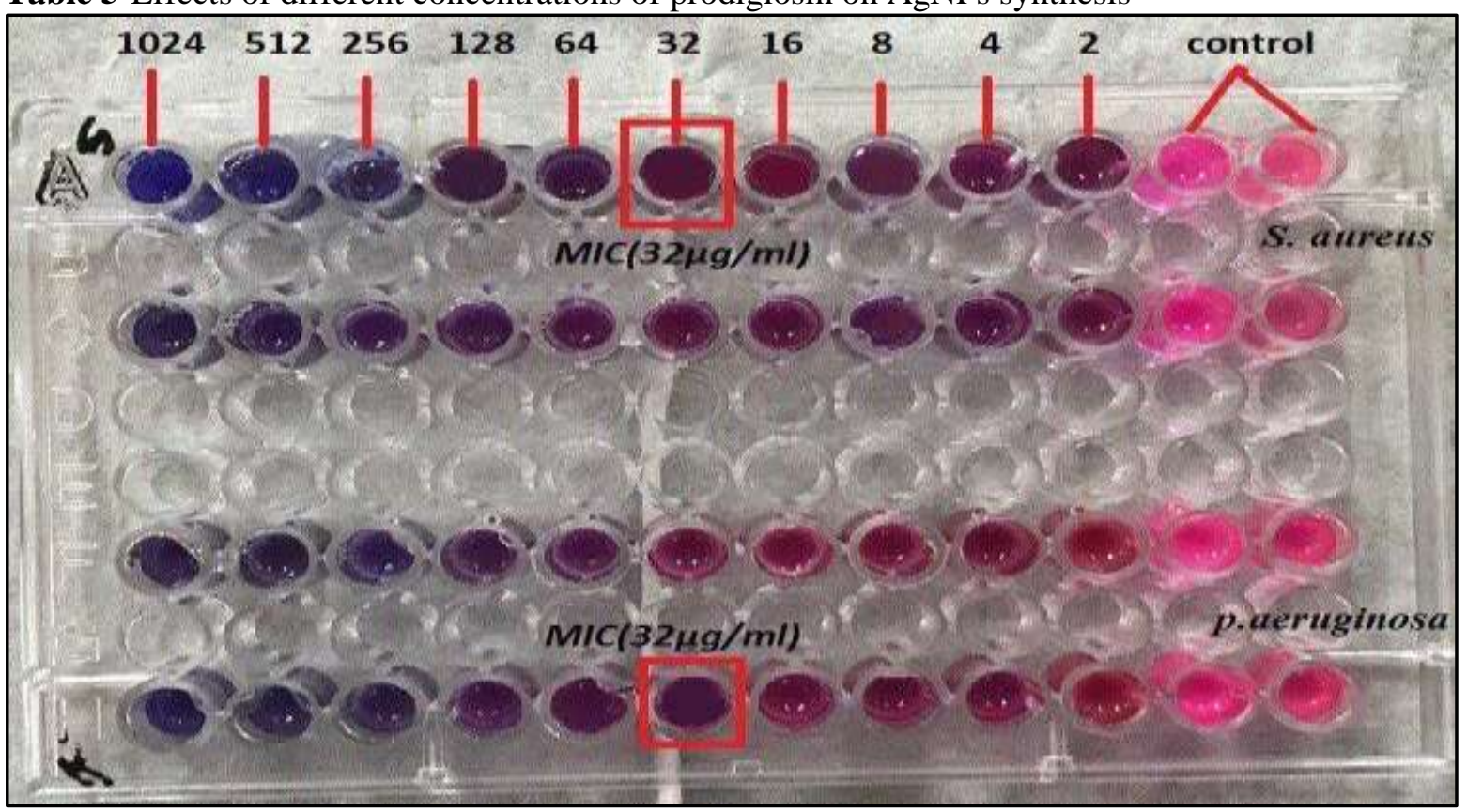

The release of $\mathrm{K}^{+}$ions from bacteria is caused by silver ions. The bacterial plasma membrane is associated with many important enzymes and DNA is an essential target site for silver ions [53]. Due to their size, AgNPs can easily enter the bacteria's nuclear content. AgNPs show a remarkably large surface area and, therefore, have increased interactions with bacteria. Silver nanoparticles synthesized by chemical means were reported to show equal antibacterial activity against $S$. typhimuium $\left(\mathrm{Gram}^{\text {-ve }}\right)$ and S. aureus $\left(\mathrm{Gram}^{+\mathrm{ve}}\right)$ [54].

\section{In vivo challenge test}

The results of the in vivo biological activity of AgNPs cream showed potent anti-inflammatory effects against the infected skin of laboratory animals (rabbits) compared with control groups (Figure14). After the injection of pathogens, the infected skin with pathogenic bacteria showed acute inflammation with abscess formation and sever congestion in different parts of the infected skin. The infection appeared after $48 \mathrm{hrs}$. The treatment of the infected animals with AgNPs cream (by wiping the infections twice daily) started at the time of the appearing of the infection and continued for 4 days until healing. As compared to the control group that was treated with fucidin ointments, the results obviously showed that the healing was beginning after the first day of treatment and completely achieved after 4 days. While the control group exhibited severe infection and congestion throughout the experiment time, in spite of treatment with fucidin. The healing condition was delayed due to severe infection (Figure-15). Additionally, it can be suggested that the AgNPs have antimicrobial effects against pathogenic bacteria. It was also concluded that small sized AgNPs (30 nm) mainly have bacteriostatic effects against $S$. aureus, possibly by adding the AgNPs to the bacteria's cell wall, where they can disturb the plasma membrane 's shape and permeability [55]. 
Tian et al. [56] demonstrated the potential role of AgNPs in animal model's wound healing, with dose - dependent fast healing and a better cosmetic appearance [57]. In addition, AgNPs showed positive effects through their antimicrobial potential, reducing wound inflammation through decreasing infiltration of lymphocytes and mast cells and modification of fibrogenic cytokines [58]. Similarly, Liu et al. [59] investigated the effects of AgNPs on dermal contraction and epidermal reepithelialisation during wound healing. They indicated that AgNPs may increase the rate of wound closure. This property was interpreted by promoting reproduction and migration of keratinocytes. Additionally, AgNPs could increase the differentiation of fibroblasts into myo-fibroblasts and thus induce wound contraction [60]. The structure of cream used in this study is similar to that described by Atwan and Hayder [61].

A

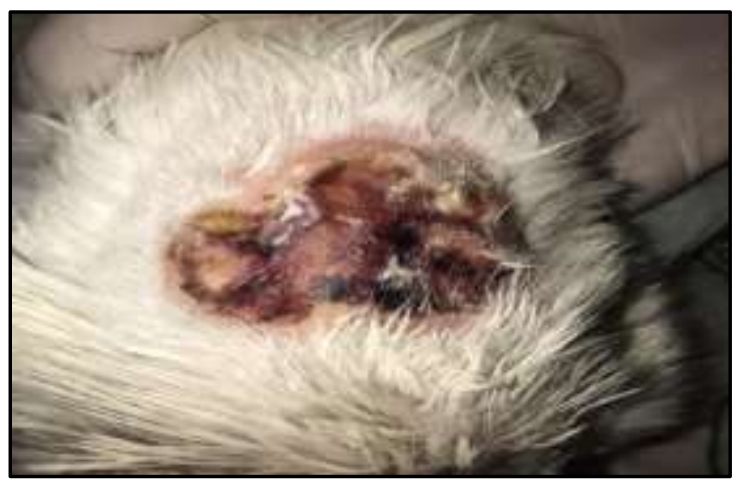

$\mathrm{C}$

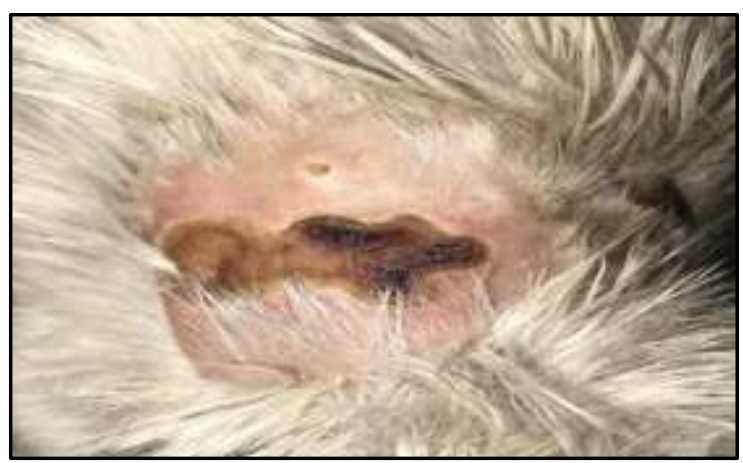

Figure 14-The healing of the infected rabbits by AgNPs cream. A and C: after infection with Pseudomonas aeruginosa and S. aureus, respectively. B and D: after treatment by AgNPs cream.

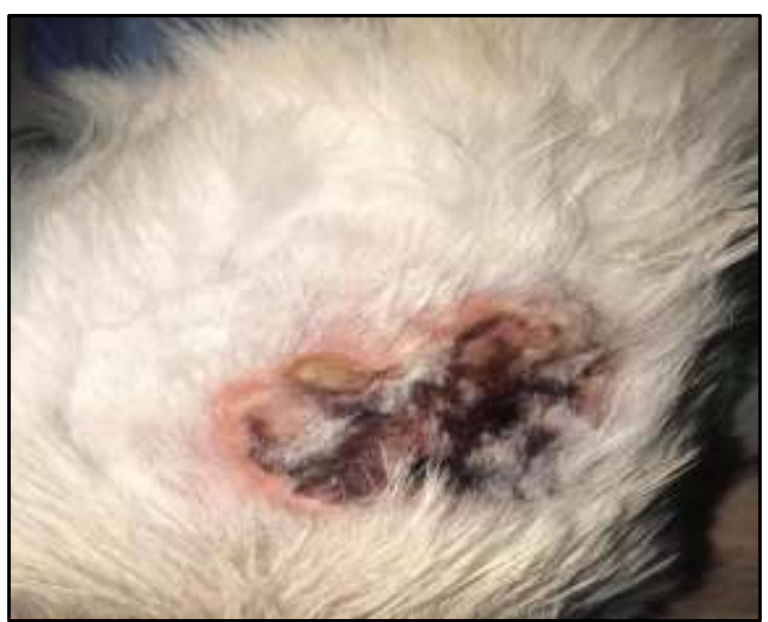

(A1)

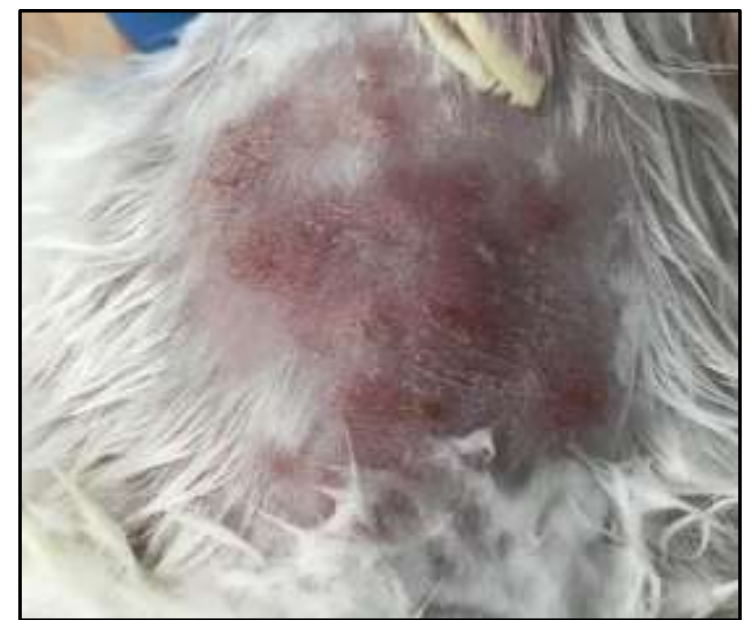

(B1) 


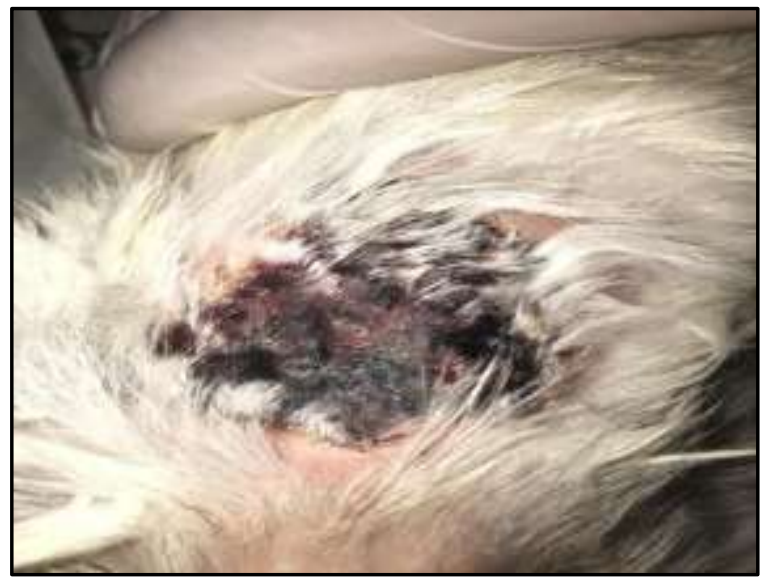

$(\mathrm{C} 1)$

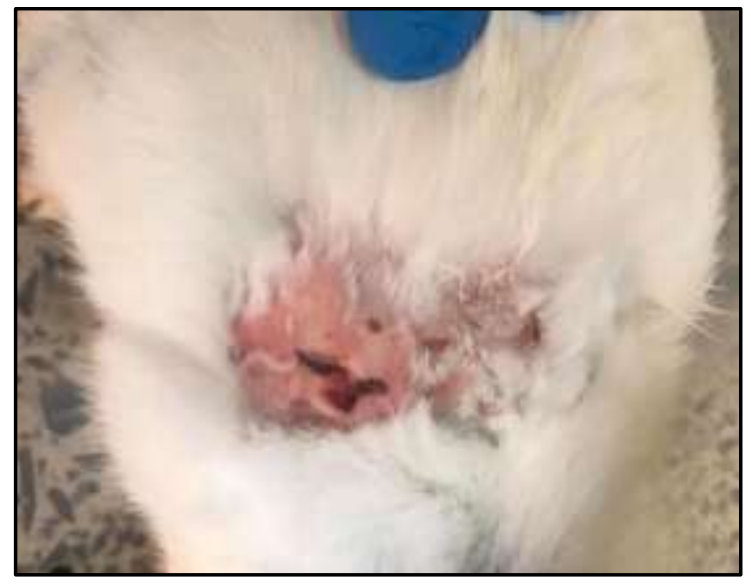

(D1)

Figure 15-The healing of the infected rabbits by fucidin cream. A1 and C1: after infection with $S$. aureus and $P$. aeruginosa, respectively. B1 and D1: after treatment by fucidin cream for four days

\section{References}

1. El-Batal, A. I. and Al Tamie, M. S. 2016. Optimization of melanin production by Aspergillus oryzae and incorporation into silver nanoparticles. Der Pharmacia Lettre, 8(2): 315-333.

2. Thakkar, K.N., Mhatre, S.S. and Rasesh, Y.P. 2010. Biological synthesis of metallic nanoparticles. Nanomedicine. 6: 257-262.

3. Sheikpranbabu, S., Kalishwaralal, K., Venkataraman, D., Eom, S. H., Park, J. and Gurunathan, S. 2009. Silver nanoparticles inhibit VEGF-and IL-1 $\beta$-induced vascular permeability via Src dependent pathway in porcine retinal endothelial cells. Journal of nanobiotechnology, 7(1): 8.

4. Karni, C., T., Langer, R., Kohane, D. S. 2012. The smartest materials: the future of nanoelectronics in medicine. ACS nano, 6(8): 6541-6545.

5. Zalevsky, Z., Mico, V., Garcia, J. 2009. Nanophotonics for optical super resolution from an information theoretical perspective: a review. Journal of Nanophotonics, 3(1): 032502.

6. Kalidindi, S. B., Jagirdar, B. R. 2012. Nanocatalysis and prospects of green chemistry. ChemSusChem, 5(1): 65-75.

7. Etheridge, M. L., Campbell, S. A., Erdman, A. G., Haynes, C. L., Wolf, S. M., McCullough, J. 2013. The big picture on nanomedicine: the state of investigational and approved nanomedicine products. Nanomedicine: nanotechnology, biology and medicine, 9(1): 1-14.

8. Prabhu, S., Poulose, E. K. 2012. Silver nanoparticles: mechanism of antimicrobial action, synthesis, medical applications, and toxicity effects. International nano letters, 2(1): 32.

9. Kavitha, R., Aiswariya, S. and Ratnavali, C. M. 2010. Anticancer activity of red pigment from Serratia marcescens in Human cervix carcinoma. International Journal of PharmTech Research, 2(1): 784-7.

10. Da Silva Melo, P., Durán, N. and Haun, M. 2000. Cytotoxicity of prodigiosin and benznidazole on V79 cells. Toxicology letters, 116(3): 237-242.

11. Boger, D.L. and Patel, M. 1988. Total synthesis of prodigiosin, prodigiosene and desmethoxyprodigiosin: Dields-Alder reactions of heterocycle azadienes and development of an effective palladium (II) promoted 2,2\%-bipyrrole coupling procedure. J. Org. Chem. 53: 14051415.

12. Chen, W. C., Yu, W. J., Chang, C. C., Chang, J. S., Huang, S. H., Chang, C. H. and Wei, Y. H. 2013. Enhancing production of prodigiosin from Serratia marcescens C3 by statistical experimental design and porous carrier addition strategy. Biochemical engineering journal, 78: 93-100. 
13. Srimathi, R., Priya, R., Nirmala, M. and Malarvizhi, A. 2017. Isolation, Identification, Optimization of Prodigiosin Pigment Produced by Serratia Marcescens and its Applications. International Journal of Latest Engineering and Management Research (IJLEMR), 2(9): 11-21.

14. Yusof, F., Chowdhury, S., Sulaiman, N. and Faruck, M. O. 2018. Effect of process parameters on the synthesis of silver nanoparticles and its effects on microbes. Jurnal Teknologi, 80(3).

15. Yusof, F., Chowdhury, S., Sulaiman, N. and Faruck, M. O. 2018. Effect of process parameters on the synthesis of silver nanoparticles and its effects on microbes. Jurnal Teknologi, 80(3).

16. Kolarević, S., Milovanović, D., Avdović, M., Oalđe, M., Kostić, J., Sunjog, K. and VukovićGačić, B. 2016. Optimisation of the microdilution method for detection of minimum inhibitory concentration values in selected bacteria. Botanica Serbica, 40(1): 29-36.

17. Atwan, Q. S. and Hayder, N. H. 2020. Eco-friendly synthesis of silver nanoparticles by using green method: improved interaction and application in vitro and in vivo. The Iraqi Journal of Agricultural Science, 51: 201-216.

18. Mathlom, G. S., Hayder, N. H. and Mahmood, M. S. 2018. Synergistic effect of biosurfactant and prodigiosin produced by Serratia marcescens as antimicrobial agent. Current Research in Microbiology and Biotechnology, 6(2): 1601-1615.

19. Cang, S., Sanada, M., Johdo, O., Ohta, S., Nagamatsu, Y. and Yoshimoto, A. 2000. High production of prodigiosin by Serratia marcescens grown on ethanol. Biotechnology letters, 22(22): 1761-1765.

20. Mathlom, G. S., Hayder, N. H. and Mahmood, M. S. 2018. Synergistic effect of biosurfactant and prodigiosin produced by Serratia marcescens as antimicrobial agent. Current Research in Microbiology and Biotechnology, 6(2): 1601-1615.

21. El-Batal, A. I., El-Hendawy, H. H. and Faraag, A. H. 2016. Synthesis and characterization of silver nanoparticles by Serratia marcescens strains isolated from different sources in Egypt. Nature and Science, 14(12).

22. El-Batal, A. I., El-Hendawy, H. H. and Faraag, A. H. 2016. Synthesis and characterization of silver nanoparticles by Serratia marcescens strains isolated from different sources in Egypt. Nature and Science, 14(12).

23. Peng, S., McMahon, J. M., Schatz, G. C., Gray, S. K. and Sun, Y. 2010. Reversing the sizedependence of surface plasmon resonances. Proc. Natl. Acad. Sci. U. S. A. 107: 14530-14534.

24. El-Batal, A. I., El-Hendawy, H. H. and Faraag, A. H. 2016. Synthesis and characterization of silver nanoparticles by Serratia marcescens strains isolated from different sources in Egypt. Nature and Science, 14(12).

25. Suber, L., Sondi, I., Matijević, E. and Goia, D. V. 2005. Preparation and the mechanisms of formation of silver particles of different morphologies in homogeneous solutions. J. Colloid Interface Sci. 288: 489-495.

26. El-Batal, A. I., El-Hendawy, H. H. and Faraag, A. H. 2016. Synthesis and characterization of silver nanoparticles by Serratia marcescens strains isolated from different sources in Egypt. Nature and Science, 14(12).

27. Suber, L., Sondi, I., Matijević, E. and Goia, D. V. 2005. Preparation and the mechanisms of formation of silver particles of different morphologies in homogeneous solutions. J. Colloid Interface Sci. 288: 489-495.

28. Alqadi, M. K., Noqtah, O. A., Alzoubi, F. Y., Alzouby, J. and Aljarrah, K. 2014. pH effect on the aggregation of silver nanoparticles synthesized by chemical reduction. Materials SciencePoland, 32(1): 107-111.

29. El-Batal, A. I., El-Hendawy, H. H. and Faraag, A. H. 2017. In silico and in vitro cytotoxic effect of prodigiosin-conjugated silver nanoparticles on liver cancer cells (HepG2). BioTechnologia. Journal of Biotechnology Computational Biology and Bionanotechnology, 98(3).

30. Li, S., Y . Shen, A. Xie, X. Yu, L. Qiu, L. Zhang and Q. Zhang. 2007. Green synthesis of silver nanoparticles using Capsicum annuum L. extract. Green Chemistry, 9(8): 852-858 
31. El-Batal, A. I., El-Hendawy, H. H. and Faraag, A. H. 2017. In silico and in vitro cytotoxic effect of prodigiosin-conjugated silver nanoparticles on liver cancer cells (HepG2). BioTechnologia. Journal of Biotechnology Computational Biology and Bionanotechnology, 98(3).

32. Phongtongpasuk, S. and Poadang, S. 2016. Green synthesis of silver nanoparticles using pomegranate peel extract. In Advanced Materials Research, 1131: 227-230.

33. Aslan, K., Lakowicz, J. R. and Geddes, C. D. 2005. Rapid deposition of triangular silver nanoplates on planar surfaces: application to metal-enhanced fluorescence. The Journal of Physical Chemistry B, 109(13): 6247-6251.

34. El-Batal, A. I., El-Hendawy, H. H. and Faraag, A. H. 2016. Synthesis and characterization of silver nanoparticles by Serratia marcescens strains isolated from different sources in Egypt. Nature and Science, 14(12).

35. Prabhu, S., Poulose, E. K. 2012. Silver nanoparticles: mechanism of antimicrobial action, synthesis, medical applications, and toxicity effects. International nano letters, 2(1): 32.

36. Vanaja, M., Rajeshkumar, S., Paulkumar, K., Gnanajobitha, G., Malarkodi, C. and Annadurai, G. 2013. Kinetic study on green synthesis of silver nanoparticles using Coleus aromaticus leaf extract. Adv. Appl. Sci. Res, 4(3): 50-55.

37. El-Batal, A. I., El-Hendawy, H. H. and Faraag, A. H. 2017. In silico and in vitro cytotoxic effect of prodigiosin-conjugated silver nanoparticles on liver cancer cells (HepG2). BioTechnologia. Journal of Biotechnology Computational Biology and Bionanotechnology, 98(3).

38. El-Batal, A. I., El-Hendawy, H. H. and Faraag, A. H. 2017. In silico and in vitro cytotoxic effect of prodigiosin-conjugated silver nanoparticles on liver cancer cells (HepG2). BioTechnologia. Journal of Biotechnology Computational Biology and Bionanotechnology, 98(3).

39. Sumathi, C., MohanaPriya, D., Swarnalatha, S., Dinesh, M. G., Sekaran, G. 2014. Production of prodigiosin using tannery fleshing and evaluating its pharmacological effects. The Scientific World Journal, 2014.

40. Patil, C. D., Patil, S. V., Salunke, B. K. and Salunkhe, R. B. 2011. Prodigiosin produced by Serratia marcescens NMCC46 as a mosquito larvicidal agent against Aedes aegypti and Anopheles stephensi. Parasitology research, 109(4): 1179-1187.

41. Sumathi, C., MohanaPriya, D., Swarnalatha, S., Dinesh, M. G., Sekaran, G. 2014. Production of prodigiosin using tannery fleshing and evaluating its pharmacological effects. The Scientific World Journal, 2014.

42. Song, M. J., Bae, J., Lee, D. S., Kim, C. H., Kim, J. S., Kim, S. W. and Hong, S. I. 2006. Purification and characterization of prodigiosin produced by integrated bioreactor from Serratia sp. KH-95. Journal of bioscience and bioengineering, 101(2): 157-161.

43. Faraag, A. H., El-Batal, A. I. and El-Hendawy, H. H. 2017. Characterization of prodigiosin produced by Serratia marcescens strain isolated from irrigation water in Egypt. Natural Science, 15: 55-68.

44. Agnihotri, S., Mukherji, S. and Mukherji, S. 2014. Size-controlled silver nanoparticles synthesized over the range 5-100 $\mathrm{nm}$ using the same protocol and their antibacterial efficacy. Rsc Advances, 4(8): 3974-3983.

45. Fadhil, F. A. and Hadi, I. H. 2015. Preparation and characterization of zinc oxide nanoparticles by laser ablation of zinc in isopropanol. Engineering and Technology Journal, 33(5 Part (B) Scientific): 791-798.

46. Ibrahim, H. M. 2015. Green synthesis and characterization of silver nanoparticles using banana peel extract and their antimicrobial activity against representative microorganisms. Journal of Radiation Research and Applied Sciences, 8(3): 265-275.

47. Ullah, A. M. A., Kabir, M. F., Akter, M., Tamanna, A. N., Hossain, A., Tareq, A. R. M. and Rahman, M. M. 2018. Green synthesis of bio-molecule encapsulated magnetic silver nanoparticles and their antibacterial activity. RSC advances, 8(65): 37176-37183.

48. Slavin, Y. N., Asnis, J., Häfeli, U. O. and Bach, H. 2017. Metal nanoparticles: understanding the mechanisms behind antibacterial activity. Journal of nanobiotechnology, 15(1): 65.

49. Dakal, T. C., Kumar, A., Majumdar, R. S. and Yadav, V. 2016. Mechanistic basis of antimicrobial actions of silver nanoparticles. Frontiers in microbiology, 7: 1831. 
50. Benjamin, G. and Bharathwaj, S. 2011. Biological synthesis of silver nanoparticles from Allium cepa (onion) and estimating its antibacterial activity. In International Conference on Bioscience, Biochemistry and Bioinformatics, 5: 35-38.

51. Karthika.D , Vadakkan.K , R.Ashwini , A. Shyamala , J. Hemapriya, Vijayanand.S. 2015. Prodigiosin Mediated Biosynthesis of Silver Nanoparticles (AgNPs) and Evaluation of its Antibacterial Efficacy. Int.J.Curr.Microbiol.App.Sci, 4(11): 868-874.

52. Karthika.D , Vadakkan.K , R.Ashwini , A. Shyamala , J. Hemapriya, Vijayanand.S. 2015. Prodigiosin Mediated Biosynthesis of Silver Nanoparticles (AgNPs) and Evaluation of its Antibacterial Efficacy. Int.J.Curr.Microbiol.App.Sci, 4(11): 868-874.

53. Kim, S. H., Lee, H. S., Ryu, D. S., Choi, S. J. and Lee, D. S. 2011. Antibacterial activity of silvernanoparticles against Staphylococcus aureus and Escherichia coli. Korean J. Microbiol. Biotechnol, 39(1): 77-85.

54. Shameli, K., Ahmad, M. B., Jazayeri, S. D., Shabanzadeh, P., Sangpour, P., Jahangirian, H. and Gharayebi, Y. 2012. Investigation of antibacterial properties silver nanoparticles prepared via green method. Chemistry Central Journal, 6(1): 73.

55. Franci, G., Falanga, A., Galdiero, S., Palomba, L., Rai, M., Morelli, G., Galdiero, M. 2015. Silver nanoparticles as potential antibacterial agents. Molecules, 20(5): 8856-8874.

56. Tian, J., Wong, K. K., Ho, C. M., Lok, C. N., Yu, W. Y., Che, C. M.,Tam, P. K. 2007. Topical delivery of silver nanoparticles promotes wound healing. ChemMedChem: Chemistry Enabling Drug Discovery, 2(1): 129-136.

57. Beddy, D., Watson, R. W. G., Fitzpatrick, J. M., O'Connell, P. R. 2004. Increased vascular endothelial growth factor production in fibroblasts isolated from strictures in patients with Crohn's disease. British journal of surgery, 91(1): 72-77.

58. Tian, J., Wong, K. K., Ho, C. M., Lok, C. N., Yu, W. Y., Che, C. M.,Tam, P. K. 2007. Topical delivery of silver nanoparticles promotes wound healing. ChemMedChem: Chemistry Enabling Drug Discovery, 2(1): 129-136.

59. Liu, X., Lee, P. Y., Ho, C. M., Lui, V. C., Chen, Y., Che, C. M. and Wong, K. K. 2010. Silver nanoparticles mediate differential responses in keratinocytes and fibroblasts during skin wound healing. ChemMedChem, 5(3): 468-475.

60. Gunasekaran, T., Nigusse, T. and Dhanaraju, M. D. 2011. Silver nanoparticles as real topical bullets for wound healing. Journal of the American college of clinical wound specialists, 3(4): 8296.

61. Atwan, Q. S. and Hayder, N. H. 2020. Eco-friendly synthesis of silver nanoparticles by using green method: improved interaction and application in vitro and in vivo. The Iraqi Journal of Agricultural Science, 51: 201-216. 